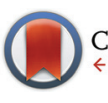

CrossMark \& click for updates

Cite this: Dalton Trans., 2016, 45 8089

Received 11th March 2016,

Accepted 29th March 2016

DOI: $10.1039 / c 6 d t 00969 \mathrm{~g}$

www.rsc.org/dalton

\title{
Suppressing the dendritic growth of zinc in an ionic liquid containing cationic and anionic zinc complexes for battery applications $\uparrow$
}

\author{
Zhen Liu, * Giridhar Pulletikurthi, Abhishek Lahiri, Tong Cui and Frank Endres*
}

\begin{abstract}
Metallic zinc is a promising negative electrode for high energy rechargeable batteries due to its abundance, low-cost and non-toxic nature. However, the formation of dendritic zinc and low Columbic efficiency in aqueous alkaline solutions during charge/discharge processes remain a great challenge. Here we demonstrate that the dendritic growth of zinc can be effectively suppressed in an ionic liquid electrolyte containing highly concentrated cationic and anionic zinc complexes obtained by dissolving zinc oxide and zinc trifluoromethylsulfonate in a protic ionic liquid, 1-ethylimidazolium trifluoromethylsulfonate. The presence of both cationic and anionic zinc complexes alters the interfacial structure at the electrode/electrolyte interface and influences the nucleation and growth of zinc, leading to compact, homogeneous and dendrite-free zinc coatings. This study also provides insights into the development of highly concentrated metal salts in ionic liquids as electrolytes to deposit dendrite-free zinc as an anode material for energy storage applications.
\end{abstract}

\section{Introduction}

Rechargeable zinc-based batteries, including $\mathrm{Zn}$-air, $\mathrm{Zn}-\mathrm{Ni}$ and $\mathrm{Zn}-\mathrm{MnO}_{2}$ batteries, are promising energy storage devices with high energy density, safety and economic feasibility. ${ }^{1-3}$ One of the main challenges that these rechargeable battery systems faces is the intrinsic properties of zinc to form dendrites during charging. These dendrites grow in subsequent deposition/stripping cycles, resulting in short circuits of the cell. Although intensive efforts have been made on preventing the formation of dendrites in aqueous and organic electrolytes, including modification of the separator, ${ }^{4}$ additives in the electrode/electrolyte, ${ }^{5-11}$ and adjustment of the deposition parameters, ${ }^{12}$ the low Columbic efficiency, hydrogen evolution in aqueous solution and safety concerns in organic solvents have limited their large-scale applications. The performance of the electrolyte is critical in the cycling stability of $\mathrm{Zn}$ anodes. The structure of the electrode/electrolyte interface has a strong influence on electrochemical reactions, ${ }^{13,14}$ as both charge transfer and mass transport processes take place at the electrode/electrolyte interface. Therefore, the exploration of an alternative non-aqueous electrolyte that can lead to long-life,

Institute of Electrochemistry, Clausthal University of Technology, Arnold-SommerfeldStraße 6, Clausthal-Zellerfeld, 38678,Germany.E-mail: zhen.liu@tu-clausthal.de, frank.endres@tu-clausthal.de

$\dagger$ Electronic supplementary information (ESI) available. See DOI: 10.1039/ c6dt00969g high rate and stable cycling of the zinc anode is critical for the development of rechargeable zinc metal batteries.

Ionic liquids (ILs) are low-temperature molten salts composed entirely of ions. ${ }^{15-17}$ ILs generally contain large asymmetric cations and weakly coordinating anions. ${ }^{18}$ They have some advantages over aqueous-based and organic solvents as electrolytes for the electrodeposition of metals and semiconductors due to their large electrochemical windows, extremely low vapor pressures and good conductivity. ${ }^{19-22}$ One of the disadvantages is that metal salts tend to be poorly soluble in ILs with weakly coordinating anions, such as trifluoromethylsulfonate $\left(\mathrm{TfO}^{-}\right), \quad$ bis(trifluoromethylsulfonyl)imide $\left(\mathrm{TFSI}^{-}\right)$, tetrafluoroborate $\left(\mathrm{BF}_{4}^{-}\right)$and hexafluorophosphate $\left(\mathrm{PF}_{6}{ }^{-}\right) .^{23}$ Alternatively, the solubility can be improved by replacing weakly coordinating anions with stronger coordinating ones like chloride, but the melting points and viscosities can increase. ${ }^{24}$ Examples for such types of liquids are composed of anions viz. $\mathrm{Al}_{2} \mathrm{Cl}_{7}^{-}$or $\mathrm{ZnCl}_{3}^{-} / \mathrm{ZnCl}_{4}{ }^{2-}$ with a combination of $\mathrm{AlCl}_{3}$ or $\mathrm{ZnCl}_{2}$ and 1,3-dialkylimidazolium chlorides. By the combination of a cation-anion of an appropriate design, the physical and chemical properties of the ILs can be modified to improve the solubility. It was reported that the solubility could be increased by functionalizing cations of the ILs (e.g. ether- or hydroxyl-functionalized ILs). ${ }^{25}$

Other approaches to overcome this drawback are to prepare cationic complexes of metal ion species by coordinating the metal salts with neutral ligands such as tertiary amines, urea and alkyl sulfides. ${ }^{26-29}$ This kind of liquid possesses cationic 
and anionic metal complexes, for instance, $\mathrm{AlCl}_{3}$ coordinates with amide, leading to the formation of an ionic compound of the formula $\left[\mathrm{AlCl}_{2} \cdot\right.$ namide $]\left[\mathrm{AlCl}_{4}\right] \cdot{ }^{27}$ Another way to synthesize the cationic metal complexes is to incorporate the metal ion as a part of cation of the IL. ${ }^{30,31}$ Since the metal ion is a part of the cation, it moves toward the cathode by electromigration under deposition conditions, which gives an advantage over anionic metal species. Another advantage is that such liquids do not possess cathodic decomposition potentials as the reduction reaction is the deposition of metal. The incorporation of metal ions in the cations of ILs gives a high concentration of metal ions, which allows an increased rate of metal deposition.

High-rate electrodeposition of zinc from ILs with $\mathrm{N}$-alkylimidazole ligands coordinated with $\mathrm{Zn}^{2+}$ cations and $\mathrm{TFSI}^{-}$ anions was described by Steichen et al. ${ }^{31}$ As another example, the IL $\left[\mathrm{Zn}\left(\mathrm{BuNH}_{2}\right)_{6}\right][\mathrm{TFSI}]_{2}$, where $\mathrm{BuNH}_{2}=$ butylamine, was reported by Huang et al. for the deposition of zinc. ${ }^{32}$ We have recently shown that the deposition of zinc is also possible from $\mathrm{ZnO} / 1$-methylimidazolium trifluoromethylsulfonate ([MIm]TfO), where cationic $\left[\mathrm{Zn}(\mathrm{MIm})_{2}\right]^{2+}$ complexes are present in the electrolyte. ${ }^{33}$ These cationic zinc containing ILs are rather viscous with high melting points, thus, electrochemical experiments have to be carried out at elevated temperatures.

In the present paper, an IL electrolyte containing both cationic and anionic zinc complexes has been explored to address these challenges. The IL electrolyte was synthesized by dissolving zinc oxide and zinc trifluoromethylsulfonate $\left(\mathrm{Zn}(\mathrm{TfO})_{2}\right)$ in a protic IL, 1-ethylimidazolium trifluoromethylsulfonate ([EIm]TfO). The highly concentrated electrolyte composed of both cationic and anionic zinc complexes results in dendritefree $\mathrm{Zn}$ deposits and a good cycling efficiency at room temperature. The interfacial properties of this IL and the nucleation/ growth of zinc are also addressed.

\section{Results and discussion}

\section{Speciation of $\mathrm{Zn}^{2+}$ in ionic liquids}

Raman spectroscopy has been employed to investigate the complex environment of zinc salts in the ionic liquid. The Raman spectra of [EIm]TfO, 0.4 M Zn(TfO $)_{2} /[\mathrm{EIm}] \mathrm{TfO}, 1.5 \mathrm{M}$ $\mathrm{ZnO} /[\mathrm{EIm}] \mathrm{TfO}$ and $\left(0.4 \mathrm{M} \mathrm{Zn}(\mathrm{TfO})_{2}+1.5 \mathrm{M} \mathrm{ZnO}\right) /[\mathrm{EIm}] \mathrm{TfO}$ in the regime of $1600-1200 \mathrm{~cm}^{-1}$ and $270-170 \mathrm{~cm}^{-1}$ are shown in Fig. 1. In the regime of $1600-1200 \mathrm{~cm}^{-1}$, the observed peaks are mainly due to vibrational modes of the imidazolium ring. ${ }^{34-36}$ For the spectra of [EIm]TfO (a) and 0.4 M Zn(TfO) $)_{2} /$ [EIm]TfO (b), the prominent peaks centered at 1583, 1550, 1453, 1411, 1297 and $1228 \mathrm{~cm}^{-1}$, as marked with rectangles in Fig. 1, are attributed to the in-plane imidazolium ring modes. The reaction of $\mathrm{ZnO}$ with [EIm]TfO results in the formation of water and cationic $\left[\mathrm{Zn}(\mathrm{EIm})_{2}\right]^{2+}$ complexes by coordination of $\mathrm{Zn}^{2+}$ ions with 1-ethylimidazole. The Raman spectra of imidazole and the imidazolium cation give different vibrational peaks. ${ }^{37,38}$ The prominent bands at $1535 \mathrm{~cm}^{-1}$ and $1328 \mathrm{~cm}^{-1}$

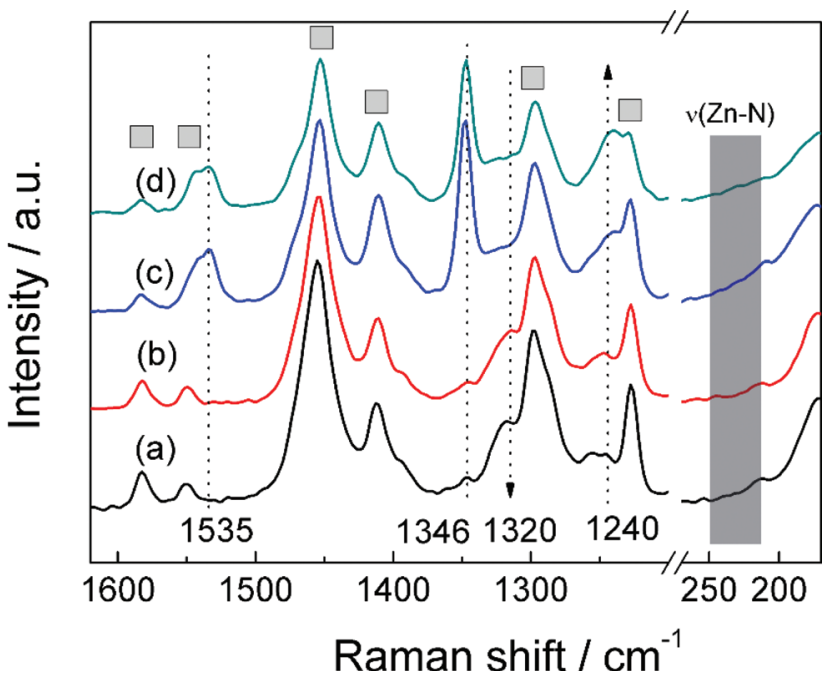

Fig. 1 Raman spectra of the ionic liquid without and with the presence of zinc salts in the regime of $1600-1200$ and $270-170 \mathrm{~cm}^{-1}$. (a) [EIm] $\mathrm{TfO}$, (b) $0.4 \mathrm{M} \mathrm{Zn(TfO})_{2} /[\mathrm{EIm}] \mathrm{TfO}$, (c) $1.5 \mathrm{M} \mathrm{ZnO/[EIm]TfO}$ and (d) $(0.4 \mathrm{M}$ $\left.\mathrm{Zn}(\mathrm{TfO})_{2}+1.5 \mathrm{M} \mathrm{ZnO}\right) /[\mathrm{EIm}] \mathrm{TfO}$

in the spectrum of imidazole, disappeared in the Raman spectrum of imidazolium. ${ }^{37,38}$ The spectra of $1.5 \mathrm{M} \mathrm{ZnO/[EIm]}$ $\mathrm{TfO}(\mathrm{c})$ and $\left(0.4 \mathrm{M} \mathrm{Zn}(\mathrm{TfO})_{2}+1.5 \mathrm{M} \mathrm{ZnO}\right) /[\mathrm{EIm}] \mathrm{TfO}(\mathrm{d})$ give rise to Raman peaks at 1535 and $1346 \mathrm{~cm}^{-1}$ as marked with dotted lines in Fig. 1, which indicates that the imidazolium cation converted to imidazole upon reaction with $\mathrm{ZnO}$. Furthermore, the geometry of the 1-ethylimdazolium ring may also alter upon reaction with $\mathrm{ZnO}$. The ethyl group of the imidazolium ring can rotate along the $\mathrm{C}-\mathrm{N}$ bond, yielding planar and nonplanar conformers, which give different Raman bands. ${ }^{39,40}$ The coordination of $\mathrm{Zn}^{2+}$ ions with the 1-ethylimidazole ring may shift the equilibrium of these conformers, which are evidenced by a decrease in peak intensity at $1320 \mathrm{~cm}^{-1}$ and an increase in peak intensity at $1240 \mathrm{~cm}^{-1}$ as indicated by arrows in Fig. 1. In addition, a peak shoulder was observed in the regime of $240-210 \mathrm{~cm}^{-1}$ for the spectra of (c) and (d), respectively, which can be due to the stretching vibration of the $\mathrm{Zn} \cdots \mathrm{N}$ bonds. The interaction of $\mathrm{Zn}^{2+}$ with the imidazolium ring was further evidenced by nuclear magnetic resonance (NMR) spectroscopy.

NMR is a useful tool to investigate the interaction between the cation and the anion of the IL. The chemical shifts $(\delta)$ for the proton resonance of the imidazolium ring without and with zinc salts are plotted in Fig. 2. The chemical shifts are found at 9.06, 7.77, 7.65, 4.20, and $1.42 \mathrm{ppm}$ for pure [EIm]TfO, which can be attributed to the proton resonance of $\mathrm{C}(2)-\mathrm{H}, \mathrm{C}(4)-\mathrm{H}, \mathrm{C}(5)-\mathrm{H},-\mathrm{CH}_{2}$ and $-\mathrm{CH}_{3}$, respectively. ${ }^{41}$ In addition, a broad peak with low intensity between 15 and $11 \mathrm{ppm}$ is also observed, which is related to the proton resonance of $\mathrm{N}-\mathrm{H}$. The addition of $\mathrm{Zn}(\mathrm{TfO})_{2}$ to [EIm]TfO leads to a downfield shift of the $\mathrm{N}-\mathrm{H}$ proton, indicating stronger hydrogen bonding between $\mathrm{TfO}^{-}$and imidazolium cations via $\mathrm{N}-\mathrm{H}$. However, the chemical shifts of $\mathrm{C}(2)-\mathrm{H}, \mathrm{C}(4)-\mathrm{H}$ and $\mathrm{C}(5)-\mathrm{H}$ do 


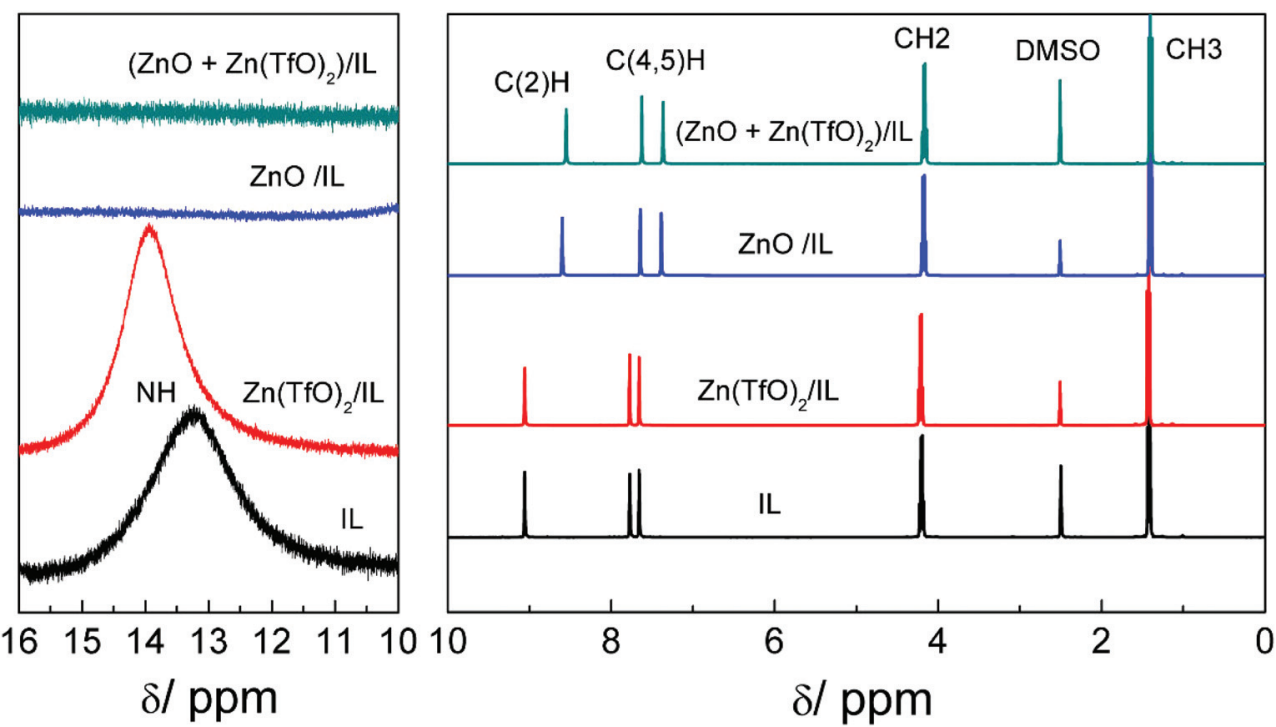

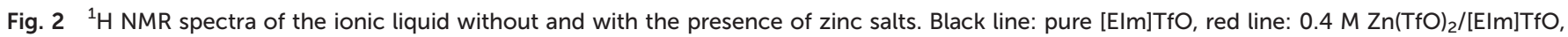
blue line: $1.5 \mathrm{M} \mathrm{ZnO/[Elm]TfO}$ and cyan line: $\left.(0.4 \mathrm{M} \mathrm{Zn(TfO})_{2}+1.5 \mathrm{M} \mathrm{ZnO}\right) /[\mathrm{Elm}] \mathrm{TfO}$.

not change their positions, suggesting that there is no prominent interaction at these positions with the anions of the ILs and/or anionic zinc complexes. Significant changes were observed upon addition of $\mathrm{ZnO}$ to [EIm]TfO and of $\mathrm{ZnO}$ to $\mathrm{Zn}(\mathrm{TfO})_{2} /[\mathrm{EIm}] \mathrm{TfO}$. The proton resonances of $\mathrm{C}(2)-\mathrm{H}, \mathrm{C}(4)-\mathrm{H}$ and $\mathrm{C}(5)-\mathrm{H}$ are upfield shifted to $8.60,7.64$ and $7.38 \mathrm{ppm}$ in $\mathrm{ZnO} /[\mathrm{EIm}] \mathrm{TfO}$ and further shifted to $8.55,7.62$ and $7.36 \mathrm{ppm}$ in $\left(\mathrm{Zn}(\mathrm{TfO})_{2}+\mathrm{ZnO}\right) /[\mathrm{EIm}] \mathrm{TfO}$. In addition, the chemical shift for $\mathrm{N}-\mathrm{H}$ disappeared, which confirms the formation of $\mathrm{Zn} \cdots \mathrm{N}$ bonds and water upon the reaction of $\mathrm{ZnO}$ with the $[\mathrm{EIm}]^{+}$ cation. The formed water molecules are not "free" in the solution, rather they interact with both $[\mathrm{EIm}]^{+}$and $\mathrm{TfO}^{-}$by hydrogen bonds via the $\mathrm{C}(2)-\mathrm{H}, \mathrm{C}(4)-\mathrm{H}$ and $\mathrm{C}(5)-\mathrm{H}$ and the $-\mathrm{SO}_{3}$ group. $^{34}$ Thus, NMR spectroscopy gives valuable insights into hydrogen bonding and $\mathrm{Zn} \cdots \mathrm{N}$ bond formation.

Raman spectroscopy is also used to investigate the environment of $\mathrm{Zn}^{2+}$ with $\mathrm{TfO}^{-}$anions by monitoring the $\mathrm{CF}_{3}$ symmetric deformation vibrational mode of the anion, $\delta_{\mathrm{s}}\left(\mathrm{CF}_{3}\right)$. In pure [EIm]TfO (Fig. 3a), the peak at $759.3 \mathrm{~cm}^{-1}$ originates from the vibrational mode of "free" $\mathrm{TfO}^{-}$anions. ${ }^{42,43}$ The peak can be well fitted by a Voigt function. On addition of $0.4 \mathrm{M}$ $\mathrm{Zn}(\mathrm{TfO})_{2}$ to the IL (Fig. 3b), a new distinct peak centered at $765.3 \mathrm{~cm}^{-1}$ is observed, which is attributed to the vibrational mode of $\mathrm{Zn}^{2+}$ coordinated $\mathrm{TfO}^{-}$. By integrating the areas of the two curves, the average number of $\mathrm{TfO}^{-}$anions coordinated to $\mathrm{Zn}^{2+}$ is calculated to be 3.1. ${ }^{42}$ This means that each $\mathrm{Zn}^{2+}$ ion is coordinated by three $\mathrm{TfO}^{-}$anions forming anionic zinc complexes of $\left[\mathrm{Zn}(\mathrm{TfO})_{3}\right]^{-}$. In $1.5 \mathrm{M} \mathrm{ZnO/IL} \mathrm{(Fig.} \mathrm{3c),} \mathrm{the} \mathrm{frequency}$ is shifted to a higher wavenumber of $761.4 \mathrm{~cm}^{-1}$ and the peak can be well fitted by a Voigt function. This shift is caused by the association of water with $\mathrm{TfO}^{-}$anions. We previously reported that the vibrational mode of $\delta_{\mathrm{s}}\left(\mathrm{CF}_{3}\right)$ shifted to higher wavenumbers upon adding water to 1-ethyl-3-methylimidazolium trifluoromethylsulfonate ([EMIm]TfO) ${ }^{42}$ The zinc complexes present in $1.5 \mathrm{M} \mathrm{ZnO/[EIm]TfO} \mathrm{are} \mathrm{cationic}$ $\left[\mathrm{Zn}(\mathrm{EIm})_{2}\right]^{2+}$, and the $\mathrm{Zn}^{2+}$ ions do not coordinate with $\mathrm{TfO}^{-}$ anions as there is only a slight shift in the free $\mathrm{TfO}^{-}$peak and no new peak/shoulder is observed at higher wavenumbers. In the mixtures of $\left(0.4 \mathrm{M} \mathrm{Zn}(\mathrm{TfO})_{2}+1.5 \mathrm{M} \mathrm{ZnO}\right) / \mathrm{IL}$, the Raman spectrum in Fig. 3d shows a broad peak at $764.1 \mathrm{~cm}^{-1}$ that can be deconvoluted into three peaks, which are centered at 758.9, 762.5 and $766.0 \mathrm{~cm}^{-1}$. They are related to free $\mathrm{TfO}^{-}$, coordinated $\mathrm{TfO}^{-}$with water, and coordinated $\mathrm{TfO}^{-}$with $\mathrm{Zn}^{2+}$. The average number of $\mathrm{TfO}^{-}$coordinated to $\mathrm{Zn}^{2+}$ is calculated to be 4.2 , giving anionic complexes like $\left[\mathrm{Zn}(\mathrm{TfO})_{4}\right]^{2-}$. The complexation of 1-ethylimidazole with $\mathrm{Zn}^{2+}$ ions weakens the interaction between $[\mathrm{EIm}]^{+}$cations and $\mathrm{TfO}^{-}$anions, which in turn favors the coordination of $\mathrm{TfO}^{-}$anions with $\mathrm{Zn}(\mathrm{TfO})_{2}$. Therefore, the zinc complexes present in $\left(0.4 \mathrm{M} \mathrm{Zn}(\mathrm{TfO})_{2}+1.5 \mathrm{M}\right.$ $\mathrm{ZnO}) / \mathrm{IL}$ are anionic $\left[\mathrm{Zn}(\mathrm{TfO})_{4}\right]^{2-}$ and cationic $\left[\mathrm{Zn}(\mathrm{EIm})_{2}\right]^{2+}$.

\section{Interfacial structure at the electrode/electrolyte interface}

The interfacial properties of the electrode/electrolyte interface have been investigated by in situ atomic force microscopy (AFM) as a function of electrode potential. The step-wise forcedistance profiles of the pure IL adopt a multilayered structure instead of a classical electric double layer. ${ }^{4-47}$ The width of each step can be due to the presence of cations, anions, or ion pairs confined between the cantilever and the electrode surface. ${ }^{48}$ Thus, the ionic composition of interfacial layers can be obtained by analyzing the widths of the steps. The interfacial structure can be divided into three regions: the innermost layer, the transition zone and the bulk liquid. ${ }^{49}$ The innermost layer of ionic species is in direct contact with the electrode surface and shows the highest order. ${ }^{50}$ Fig. 4a shows the force-distance curves of $[\mathrm{EIm}] \mathrm{TfO}$ at $-0.3 \mathrm{~V}$. A similar force-distance behavior was observed at the open circuit potential (OCP) as shown in ESI Fig. S1† and therefore only 

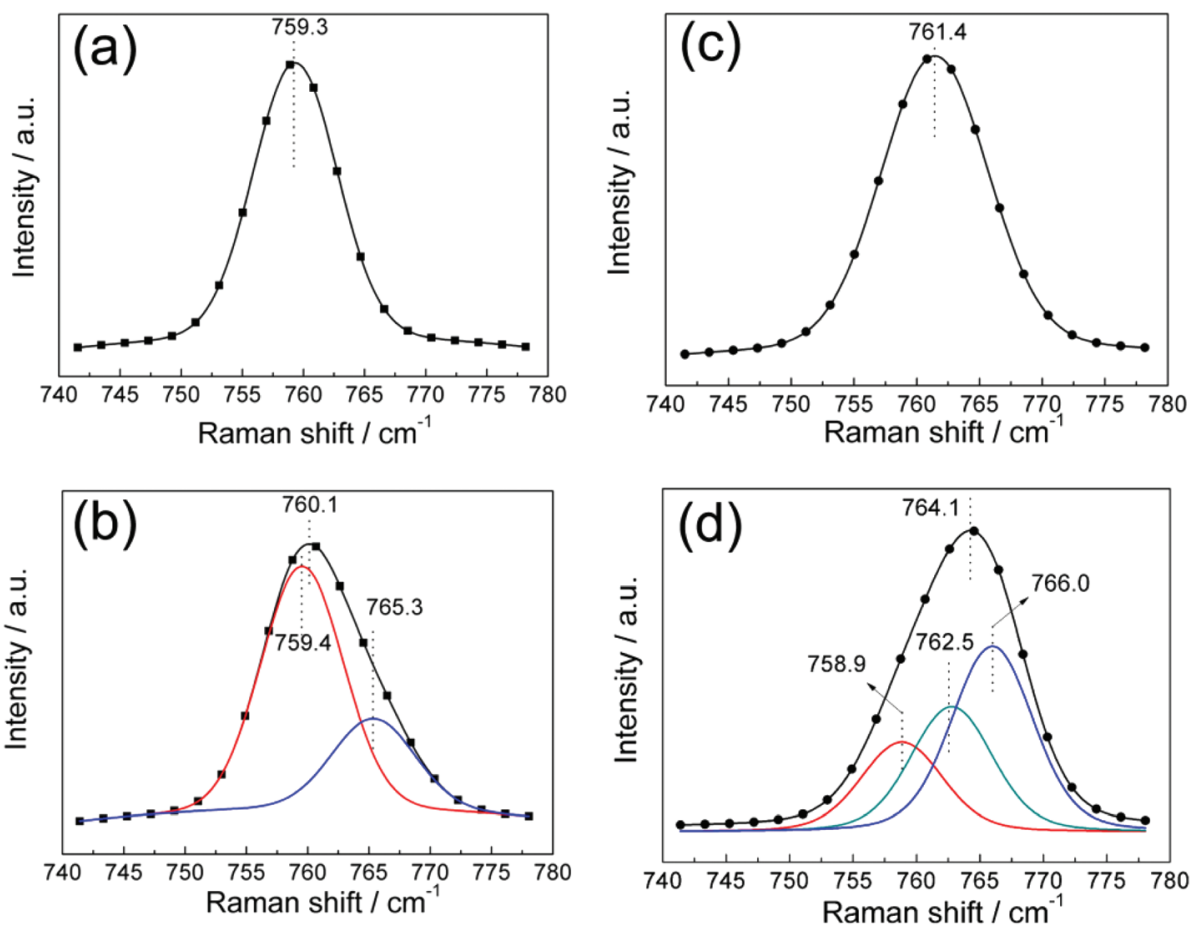

Fig. 3 Coordinating environment of $\mathrm{Zn}^{2+}$ with $\mathrm{TfO}^{-}$anions investigated by Raman spectroscopy in the regime of $740-780 \mathrm{~cm}^{-1}$. (a) [Elm] TfO, (b) $0.4 \mathrm{M} \mathrm{Zn}(\mathrm{TfO})_{2} /[\mathrm{Elm}] \mathrm{TfO}$, (c) $1.5 \mathrm{M} \mathrm{ZnO/[Elm]TfO}$ and (d) $\left(0.4 \mathrm{M} \mathrm{Zn}(\mathrm{TfO})_{2}+1.5 \mathrm{M} \mathrm{ZnO}\right) /[\mathrm{Elm}] \mathrm{TfO}$.
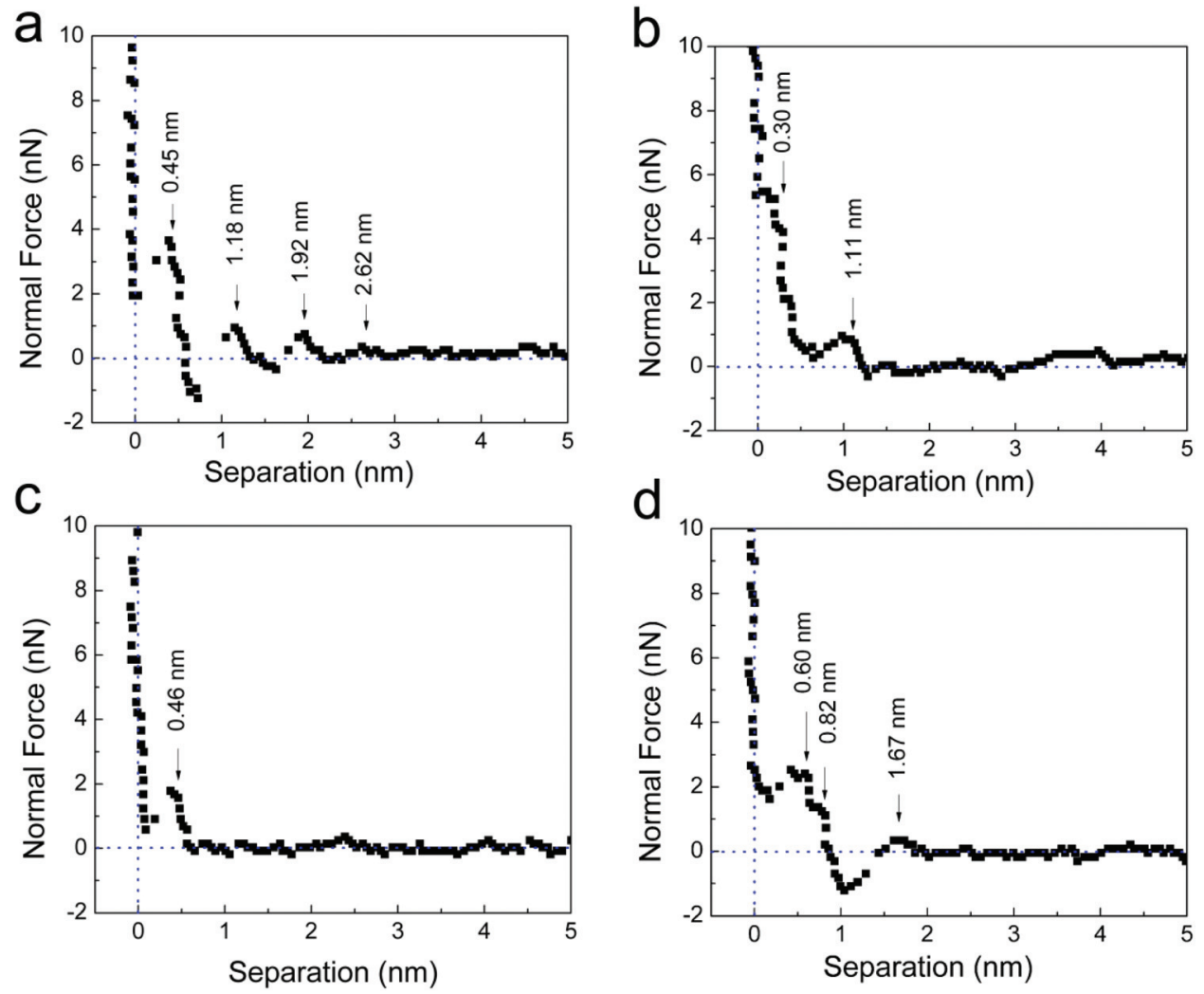

Fig. 4 Force versus apparent separation profiles for a silica cantilever approaching an $\mathrm{Au}$ (111) surface in different solutions. (a) [Elm]TfO, (b) $0.4 \mathrm{M}$ $\mathrm{Zn}(\mathrm{TfO})_{2} /[\mathrm{Elm}] \mathrm{TfO}$, (c) $1.5 \mathrm{M} \mathrm{ZnO/[EIm]TfO}$ and (d) $\left.(1.5 \mathrm{M} \mathrm{ZnO}+0.4 \mathrm{M} \mathrm{Zn(TfO})_{2}\right) /[\mathrm{Elm}] \mathrm{TfO}$ at $-0.3 \mathrm{~V}$. 
the force-distance at $-0.3 \mathrm{~V}$ is discussed here. In Fig. $4 \mathrm{a}$, the pure IL shows four discrete steps. The widths of these steps are $0.45,1.18,1.94$, and $2.62 \mathrm{~nm}$, respectively. The [EIm]TfO ion pair has a diameter of $0.67 \mathrm{~nm}$ estimated by assuming a cubic packing geometry. ${ }^{51}$ As the innermost layer separation is $0.45 \mathrm{~nm}$ and is negative to OCP, it appears that a highly ordered ion-pair exists at the Au (111) surface with the [EIm] $]^{+}$ cations possibly adopting a planar configuration. ${ }^{52}$ The second, third and fourth layers have a separation distance of $\sim 0.72 \mathrm{~nm}$, indicating the presence of [EIm]TfO ion pairs. On addition of $0.4 \mathrm{M} \mathrm{Zn}(\mathrm{TfO})_{2}$, the force-distance curve at $-0.3 \mathrm{~V}$ in Fig. 4b shows that the width of the innermost layer is lowered to $0.3 \mathrm{~nm}$ with a force of $5.5 \mathrm{nN}$. Also the innermost layer appears to have a gradient with multiple steps. The Raman spectrum in Fig. $3 \mathrm{~b}$ has revealed that $\mathrm{Zn}^{2+}$ coordinates with $\mathrm{TfO}^{-}$forming $\left[\mathrm{Zn}(\mathrm{TfO})_{3}\right]^{-}$complexes. Therefore, it is imaginable that the surface is enriched with $[\mathrm{EIm}]^{+}$cations along with coordinated $\mathrm{Zn}$ ions leading to a decrease in the innermost layer compared to the pure IL. The second layer is separated by $0.81 \mathrm{~nm}$ from the innermost layer, which is larger than the dimension of [EIm]TfO ion pairs and can be related to the presence of both [EIm]TfO and zinc complexes of $\left[\mathrm{Zn}(\mathrm{TfO})_{3}\right]^{-}$. The force-distance profile of $1.5 \mathrm{M} \mathrm{ZnO/[EIm]TfO}$ in Fig. $4 \mathrm{c}$ shows only one interfacial layer with a width of $0.46 \mathrm{~nm}$. Although the width of the innermost layer is similar to that of the pure IL, the interfacial structure must be different as further layers are not observed compared to Fig. 4a. From Raman and NMR spectra, it is evident that $\mathrm{Zn}^{2+}$ reacts with the imidazolium cation forming cationic $\left[\mathrm{Zn}(\mathrm{EIm})_{2}\right]^{2+}$ complexes, which probably together with $\mathrm{TfO}^{-}$anions are present on the surface. In the mixtures of $\left(1.5 \mathrm{M} \mathrm{ZnO}+0.4 \mathrm{M} \mathrm{Zn}(\mathrm{TfO})_{2}\right) /$ $[\mathrm{EIm}] \mathrm{TfO}$, both cationic $\left[\mathrm{Zn}(\mathrm{EIm})_{2}\right]^{2+}$ complexes and anionic $\left[\mathrm{Zn}(\mathrm{TfO})_{4}\right]^{2-}$ complexes are present in the solution. The forcedistance profile is shown in Fig. 4d. The interfacial layers appear quite wide and rather distorted, showing an average separation of $\sim 0.80 \mathrm{~nm}$. It appears that more than one species is present in the innermost layer. The interfacial layer cannot be probed at potentials more negative than $-0.4 \mathrm{~V}$ due to the underpotential deposition of zinc or due to alloying of zinc with gold. Thus, from AFM analysis, it can be concluded that the presence of different zinc species changes the interfacial structure significantly which will lead to different electrochemical processes during zinc deposition/stripping.

\section{Electrochemical behavior}

The electrodeposition of $\mathrm{Zn}$ on gold from these electrolytes has been studied using cyclic voltammetry and chronoamperometry. The cyclic voltammograms (CV) of pure IL, $0.4 \mathrm{M}$ $\mathrm{Zn}(\mathrm{TfO})_{2} / \mathrm{IL}, 1.5 \mathrm{M} \mathrm{ZnO} / \mathrm{IL}$, and (0.4 M Zn(TfO $\left.)_{2}+1.5 \mathrm{M} \mathrm{ZnO}\right) /$ $\mathrm{IL}$ at room temperature are shown in Fig. 5a. The decomposition of $[\mathrm{EIm}]^{+}$cations starts early at $-1.0 \mathrm{~V}$ on a gold substrate. In $0.4 \mathrm{M} \mathrm{Zn(TfO})_{2} / \mathrm{IL}$ (Fig. 5a, black curve), the onset of $\mathrm{Zn}^{2+}$ reduction occurs at $-1.4 \mathrm{~V}$ and shows a reduction peak (c1) at $-1.8 \mathrm{~V}$ with a current density of $\sim 3 \mathrm{~mA} \mathrm{~cm}{ }^{-2}$. In the backward scan, a current cross over is recorded at $-1.3 \mathrm{~V}$. This current loop is indicative of a nucleation process. The oxidation peak (a1) is attributed to the stripping of zinc and the stripping efficiency is $\sim 95 \%$ as calculated by integration of the current densities in the $\mathrm{CV}$. The addition of $\mathrm{Zn}(\mathrm{TfO})_{2}$ to [EIm]TfO widens the electrochemical window of the electrolyte. Upon addition of $\mathrm{ZnO}$ to the $\mathrm{IL}$ and to $\mathrm{Zn}(\mathrm{TfO})_{2} / \mathrm{IL}$, the CVs change their shapes. The reaction of $\mathrm{ZnO}$ with the imidazolium cation results in the association of $\mathrm{Zn}^{2+}$ with 1-ethylimidazole by the replacement of $\mathrm{H}$ from the imidazolium cation, which enhances the electrochemical stability of the electrolyte. In addition, the cationic $\left[\mathrm{Zn}(\mathrm{EIm})_{2}\right]^{2+}$ complexes can move towards the cathode during electrodeposition not only by diffusion but also by electric field. In $1.5 \mathrm{M} \mathrm{ZnO/IL}$ (Fig. 5a, red curve), the reduction of zinc occurs at $-1.45 \mathrm{~V}$ and has a lower current density compared to that in $0.4 \mathrm{M}$ $\mathrm{Zn}(\mathrm{TfO})_{2} / \mathrm{IL}$, because the former has a higher viscosity $\left(262 \mathrm{mPa} \mathrm{s}\right.$ at $\left.25^{\circ} \mathrm{C}\right)$ than the latter $\left(81 \mathrm{mPa} \mathrm{s}\right.$ at $\left.25^{\circ} \mathrm{C}\right)$. In
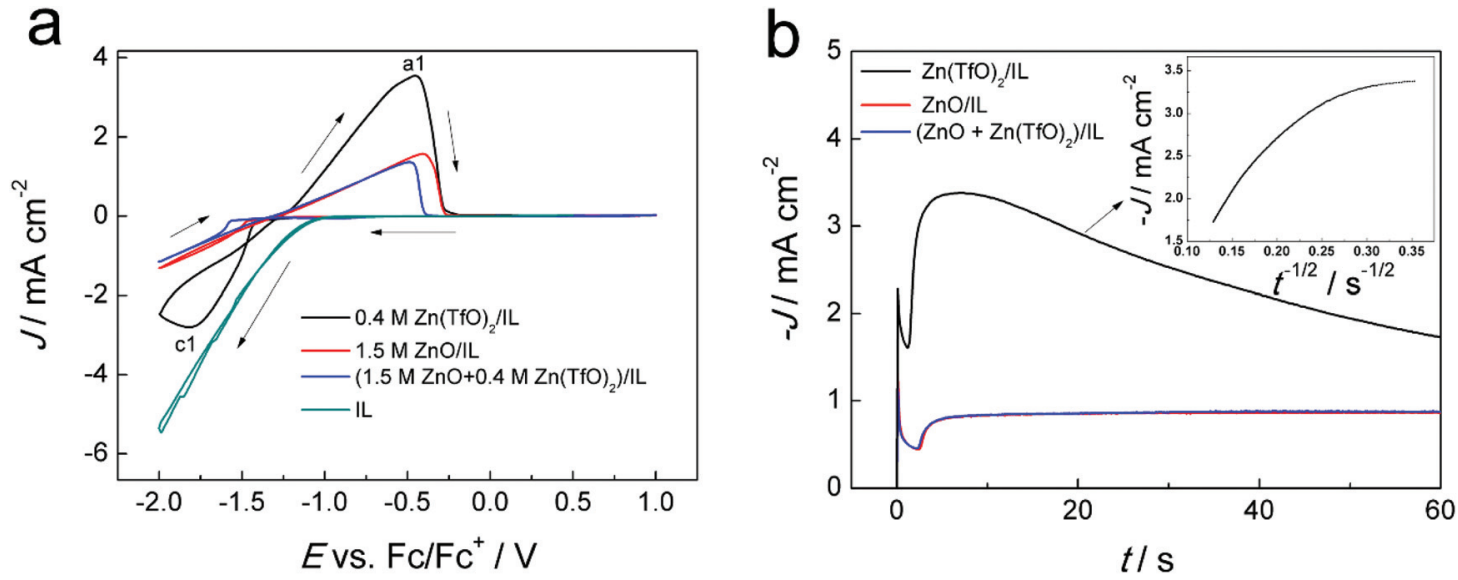

Fig. 5 Electrochemical characterization of these electrolytes on gold substrates. (a) Cyclic voltammograms of pure IL, $0.4 \mathrm{M} \mathrm{Zn}(\mathrm{TfO})_{2} / \mathrm{IL}, 1.5 \mathrm{M}$ $\mathrm{ZnO} / \mathrm{IL}$, and $\left(0.4 \mathrm{M} \mathrm{Zn}(\mathrm{TfO})_{2}+1.5 \mathrm{M} \mathrm{ZnO}\right) / \mathrm{IL}$, respectively, on gold substrates at room temperature. Scan rate: $10 \mathrm{mV} \mathrm{s}^{-1}$. (b) Current-time transients of gold substrates in $0.4 \mathrm{M} \mathrm{Zn}(\mathrm{TfO})_{2} / \mathrm{IL}, 1.5 \mathrm{M} \mathrm{ZnO} / \mathrm{IL}$, and $\left(0.4 \mathrm{M} \mathrm{Zn}(\mathrm{TfO})_{2}+1.5 \mathrm{M} \mathrm{ZnO}\right) / \mathrm{IL}$, respectively, at $-1.8 \mathrm{~V}$ for $60 \mathrm{~s}$. Inset: Cottrell analysis of current transients for $0.4 \mathrm{M} \mathrm{Zn(TfO})_{2} / \mathrm{IL}$. 
$\left(0.4 \mathrm{M} \mathrm{Zn}(\mathrm{TfO})_{2}+1.5 \mathrm{M} \mathrm{ZnO}\right) / \mathrm{IL}$ (with a viscosity of $362 \mathrm{mPa} \mathrm{s}$ at $25^{\circ} \mathrm{C}$ ), the $\mathrm{CV}$ (Fig. 5a, blue curve) looks similar to that of 1.5 $\mathrm{M} \mathrm{ZnO} / \mathrm{IL}$ but with a slightly lower current density. In both cases, no cathodic peak is observed in the investigated potential regime. The results are consistent with previous reports on metal deposition from cationic metal containing ILs, where the authors suggested that the deposition process is not limited by mass transport..$^{30,31,53}$

Nucleation and growth kinetics in the initial stages of $\mathrm{Zn}$ deposition on gold are studied by chronoamperometry. Fig. 5b shows typical current transients for $\mathrm{Zn}$ deposition from these electrolytes at $-1.8 \mathrm{~V}$. In $0.4 \mathrm{M} \mathrm{Zn}(\mathrm{TfO})_{2} / \mathrm{IL}$, the transient is characterized by an initial increase in the current at short times and then a decay $(t=1.2 \mathrm{~s})$. Subsequently there is a rapid rise in the curve to a peak $(t=6.5 \mathrm{~s})$ followed by a gradual decay. The transient exhibits a typical shape for metal deposition involving nucleation and growth. The inset of Fig. $5 \mathrm{~b}$ presents $j$ versus $t^{-1 / 2}$ plot for the descending parts of the transient for $0.4 \mathrm{M} \mathrm{Zn}(\mathrm{TfO})_{2} / \mathrm{IL}$. As seen, the transient deviates from the Cottrell's behavior. Since the electrode potential is in the range of the hydrogen evolution potential (Fig. 4, cyan curve), it is expected that proton reduction simultaneously occurred during $\mathrm{Zn}$ electrodeposition, which affects the diffusion process. However, for $\mathrm{ZnO}$ containing electrolytes without and with $\mathrm{Zn}(\mathrm{TfO})_{2}$, the deposition mechanism is considerably different. In both cases, the transients are characterized by a sharp increase in the current and then a decay $(t=$ $2.5 \mathrm{~s})$. In the succeeding part of the transient, a rise in the current is recorded at $t>2.5 \mathrm{~s}$ and almost constant current is recorded at $t>5 \mathrm{~s}$. Despite the differences in zinc species, zinc concentrations and viscosity, the transients of the two $\mathrm{ZnO}$ containing electrolytes are similar. The results suggest that both the cationic and anionic zinc complexes in $(0.4 \mathrm{M}$ $\left.\mathrm{Zn}(\mathrm{TfO})_{2}+1.5 \mathrm{M} \mathrm{ZnO}\right) / \mathrm{IL}$ are reduced in the investigated overpotential $(-1.8 \mathrm{~V})$. A synergetic effect may exist between cationic and anionic zinc species in the nucleation and growth of zinc.

\section{Morphology of the zinc deposits}

Earlier results in the literature showed that zinc dendritic growth preferentially occurs at the edges and along the boundaries of the electrode where the current density is higher compared to the center. ${ }^{54,55}$ Therefore, the morphologies of the zinc deposits obtained at the edge and at the center region of the deposits in the electrolytes of $1.5 \mathrm{M} \mathrm{ZnO} / \mathrm{IL}, 0.4 \mathrm{M}$ $\mathrm{Zn}(\mathrm{TfO})_{2} / \mathrm{IL}$ and $\left(0.4 \mathrm{M} \mathrm{Zn}(\mathrm{TfO})_{2}+1.5 \mathrm{M} \mathrm{ZnO}\right) / \mathrm{IL}$ at $-1.8 \mathrm{~V}$ for $2 \mathrm{~h}$, respectively, were investigated by scanning electron microscopy (SEM). The images are shown in Fig. 6. The zinc deposits obtained from $1.5 \mathrm{M} \mathrm{ZnO} / \mathrm{IL}$ show dendrites which are perpendicular to the surface both at the edges and the center region of the deposits (Fig. 6a and b). For the zinc deposits obtained from $0.4 \mathrm{M} \mathrm{Zn(TfO})_{2} / \mathrm{IL}$, granular zinc particles were seen at the edges (Fig. 6c) while compact and dense zinc deposits with a hexagonal structure were observed in the center region (Fig. 6d). The [EIm] $]^{+}$cations can be decomposed and they can generate hydrogen bubbles during zinc deposition and edges are the preferential sites for hydrogen embrittlement. Therefore, granular zinc aggregates with poor adhesion to the substrate were found at the edges. In contrast, compact and dendrite-free zinc was successfully electrodeposited from (0.4 M Zn(TfO) $\left.)_{2}+1.5 \mathrm{M} \mathrm{ZnO}\right) / \mathrm{IL}$ (Fig. 6e and f). The deposits are bright and have a uniform crystal size. A hexagonal-shaped zinc structure can be seen in the insets of Fig. 6e and $\mathrm{f}$. In addition, the XRD results (ESI Fig. S2†) show that for the electrolytes of $1.5 \mathrm{M} \mathrm{ZnO} / \mathrm{IL}$ and $0.4 \mathrm{M} \mathrm{Zn(TfO})_{2} / \mathrm{IL}$, the zinc deposits have a preferred (101) orientation, while it is a (002) orientation for $\left(0.4 \mathrm{M} \mathrm{Zn}(\mathrm{TfO})_{2}+1.5 \mathrm{M} \mathrm{ZnO}\right) / \mathrm{IL}$.

\section{Cycling stability}

To evaluate the feasibility of the $\left(\mathrm{Zn}(\mathrm{TfO})_{2}+\mathrm{ZnO}\right) / \mathrm{IL}$ electrolyte towards practical applications, a current density of $2 \mathrm{~mA} \mathrm{~cm} \mathrm{~cm}^{-2}$ is applied for cycling tests. The cycling behavior of zinc in $0.4 \mathrm{M} \mathrm{Zn}(\mathrm{TfO})_{2} / \mathrm{IL}$ and in $1.5 \mathrm{M} \mathrm{ZnO} / \mathrm{IL}$ has also been investigated for comparison. The voltage profiles are shown in Fig. 7a-c. In 0.4 M Zn(TfO) $2 / \mathrm{IL}$ (Fig. 7a), a charge over-voltage of $\sim-0.35 \mathrm{~V}$ and a discharge over-voltage of $\sim 0.4 \mathrm{~V}$ are observed, respectively, and they are stable for the initial 50 cycles. With increasing cycle numbers (>100 cycles), a rapid increase in the over-voltage is recorded after $600 \mathrm{~s}$. At these higher over-potentials, decomposition of imidazolium cations and side reactions probably occur, decreasing the Columbic efficiency of the cell and leading to an uneven growth of the deposits. In 1.5 M ZnO/IL (Fig. 7b), the charge voltage profile is not flat, but it gradually increases as charging proceeds. In addition, the charge voltage also gradually increases as the cycling number increases. Dendritic growth of $\mathrm{Zn}$ deposits as shown in Fig. $6 \mathrm{a}$ and $\mathrm{b}$ leads to uneven distribution of the current on electrode's surface, resulting in instability of the voltage. However, the discharge voltage is almost stable at $\sim 0.95 \mathrm{~V}$ for the initial 50 cycles and a rapid rise in the overpotential is observed in the last $200 \mathrm{~s}$ after 100 cycles. In $\left(0.4 \mathrm{M} \mathrm{Zn}(\mathrm{TfO})_{2}+1.5 \mathrm{M} \mathrm{ZnO}\right) / \mathrm{IL}$ (Fig. 7c), relatively flat voltage profiles are seen during charge and discharge. The charge voltage is observed in the range of $-0.90--1.1 \mathrm{~V}$ in the initial cycles, which gradually polarizes each cycle to $-1.1--1.3 \mathrm{~V}$ in the $170^{\text {th }}$ cycle. The discharge voltage is stable at $\sim 0.95 \mathrm{~V}$. The cell with $\left(0.4 \mathrm{M} \mathrm{Zn}(\mathrm{TfO})_{2}+1.5 \mathrm{M} \mathrm{ZnO}\right) / \mathrm{IL}$ as the electrolyte is able to cycle well with a stable voltage and supports a reversible reaction.

Fig. $7 d-i$ show the optical and SEM images of electrodes after 170 cycles. Several hollow shell like structures are found in $\mathrm{Zn}$ (TfO) $)_{2} / \mathrm{IL}$ (Fig. 7d and g). Obviously, dendritic aggregates are found in $\mathrm{ZnO} / \mathrm{IL}$ (Fig. 7e and h). The formation of zinc dendrites tends to cause short circuits of the cell. In contrast, for the $\left(\mathrm{Zn}(\mathrm{TfO})_{2}+\mathrm{ZnO}\right) / \mathrm{IL}$ electrolyte, homogeneous and dendrite-free zinc deposits are obtained (Fig. 7f and i).

\section{Discussion}

The dissolution of metal oxides such as $\mathrm{Ag}_{2} \mathrm{O}, \mathrm{NiO}, \mathrm{CuO}$, and $\mathrm{ZnO}$ in 1,3-dialkylimidazolium ILs is described in the literature. ${ }^{56}$ The dissolution occurs through a deprotonation of 

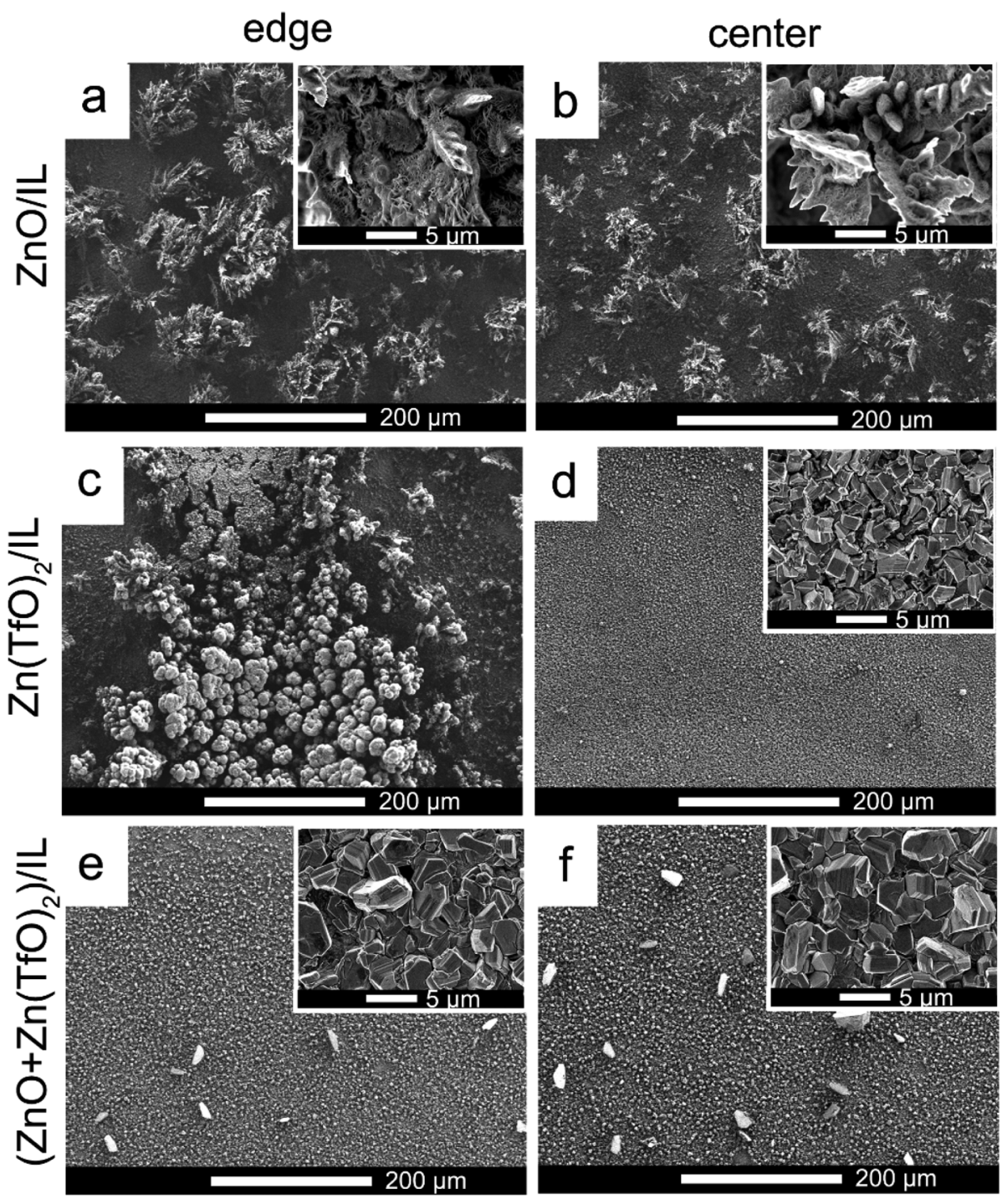

Fig. 6 Morphologies of zinc deposits on gold substrates. SEM images of zinc deposits at the edge and at the center regions of gold substrates obtained by electrolysis at $-1.8 \mathrm{~V}$ for $2 \mathrm{~h}(\mathrm{a}, \mathrm{b})$ from $1.5 \mathrm{M} \mathrm{ZnO} / \mathrm{LL}$, (c, d) from $0.4 \mathrm{M} \mathrm{Zn(TfO})_{2} / \mathrm{IL}$ and $(\mathrm{e}, \mathrm{f})$ from $\left(0.4 \mathrm{M} \mathrm{Zn}(\mathrm{TfO})_{2}+1.5 \mathrm{M} \mathrm{ZnO}\right) / \mathrm{IL}$, respectively.

$\mathrm{C}(2)-\mathrm{H}$ of the imidazolium cation, resulting in the formation of Ag-carbene complexes and water. In our case, we have C(2)$\mathrm{H}$ and $\mathrm{N}-\mathrm{H}$ in the employed protic IL. The question arises here is which ' $\mathrm{H}$ ' is deprotonated upon the reaction with $\mathrm{ZnO}$. The proton of $\mathrm{N}-\mathrm{H}$ is more acidic than the $\mathrm{C}(2)-\mathrm{H}$ of the imidazole ring. Thus, deprotonation preferably occurs at $\mathrm{N}-\mathrm{H}$. In the NMR spectra, the proton resonance of $\mathrm{N}-\mathrm{H}$ after the reaction with $\mathrm{ZnO}$ is missing. In the case of Raman spectra, the $\mathrm{TfO}^{-}$ anion signal is slightly shifted from 759.3 to $761.4 \mathrm{~cm}^{-1}$, which can be due to the association of water with $\mathrm{TfO}^{-}$ anions. ${ }^{42}$ However, we could not find a drastic change in the anion environment for the coordination of $\mathrm{TfO}^{-}$anions with $\mathrm{Zn}^{2+}$ like in the case of $\mathrm{Zn}(\mathrm{TfO})_{2} /[\mathrm{EIm}] \mathrm{TfO}$ in Fig. $3 \mathrm{~b}$. Thus, the reaction of $\mathrm{ZnO}$ with [EIm]TfO probably yields $\left[\mathrm{Zn}(\mathrm{EIm})_{2}\right]^{2+}$ cations and $[\mathrm{TfO} \cdots \mathrm{HOH} \cdots \mathrm{OfT}]^{2-}$ anions. In the case of $\mathrm{Zn}(\mathrm{TfO})_{2} /[\mathrm{EIm}] \mathrm{TfO}$, we observed $\left[\mathrm{Zn}(\mathrm{TfO})_{3}\right]^{-}$complexes as major $\mathrm{Zn}^{2+}$ species. However, these species might be in the form of $\left[\mathrm{Zn}(\mathrm{EIm})_{2}\right]^{2+}$ along with $\left[\mathrm{Zn}(\mathrm{TfO})_{4}\right]^{2-}$ in $(\mathrm{ZnO}+$ $\left.\mathrm{Zn}(\mathrm{TfO})_{2}\right) /[\mathrm{EIm}] \mathrm{TfO}$.

The zinc morphology in Fig. 6 shows that a dendritic deposit occurs on addition of $\mathrm{ZnO}$ whereas a spherical deposit is formed in the presence of $\mathrm{Zn}(\mathrm{TfO})_{2}$ in the ionic liquid. In the presence of both salts, a very fine $\mathrm{Zn}$ deposit is obtained. The changes in the morphology can be associated with the interfacial structure shown in Fig. 4. It is evident that the innermost interfacial layer significantly changes on addition of $\mathrm{Zn}(\mathrm{TfO})_{2}$ and of $\mathrm{Zn}(\mathrm{TfO})_{2}+\mathrm{ZnO}$ compared to the pure IL, whereas in the case of $\mathrm{ZnO}$ addition, no change occurs. This suggests that the change in the innermost layer affects the zinc deposition process. Furthermore, in the case of $\mathrm{Zn}(\mathrm{TfO})_{2}+$ $\mathrm{ZnO}$, the innermost layer appears to show the presence of more than one species (Fig. 4d) which might have led to the 

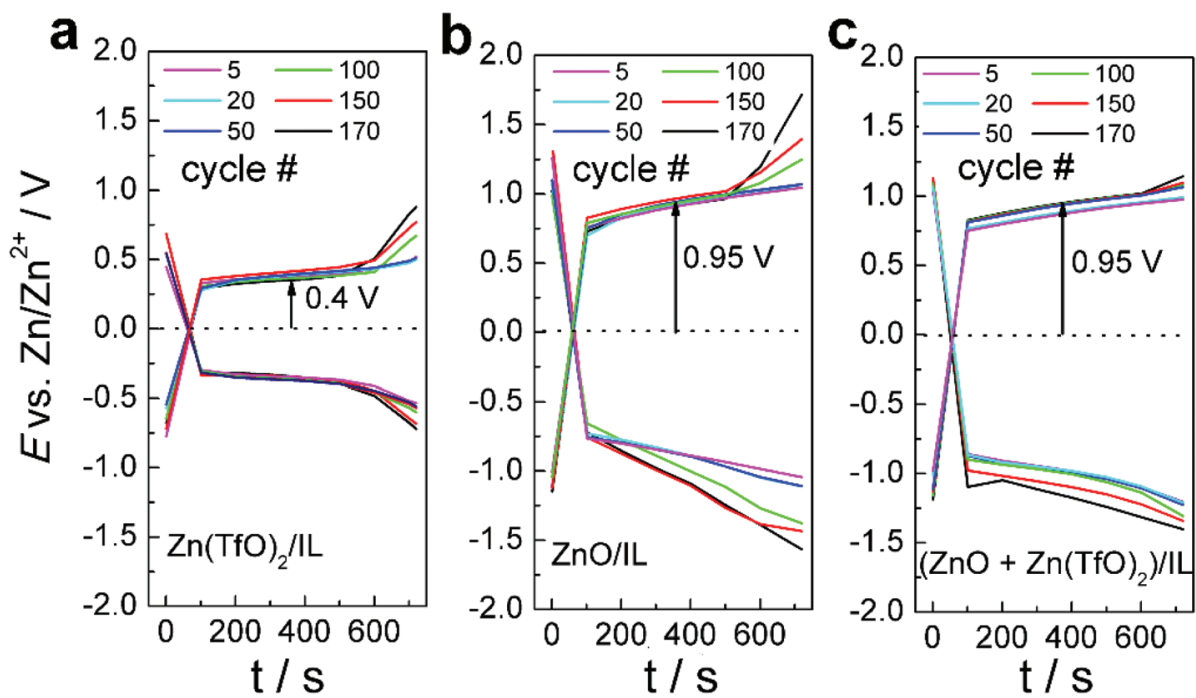

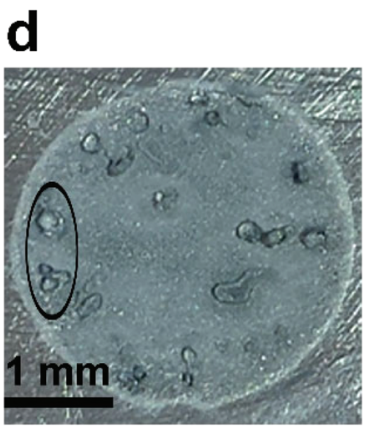

e
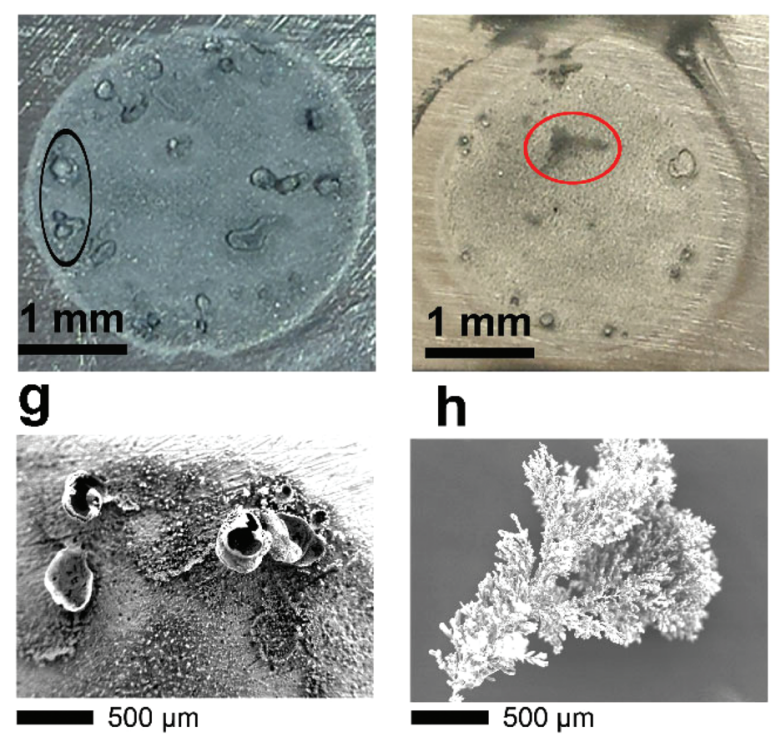
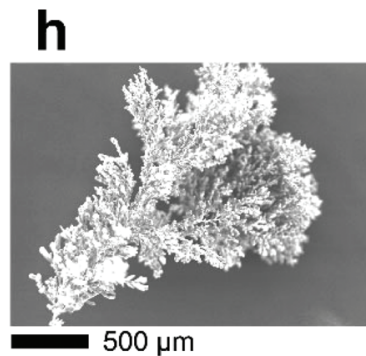

f

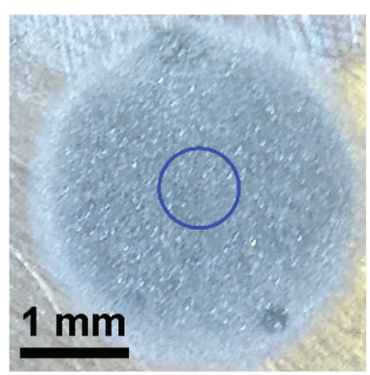

i

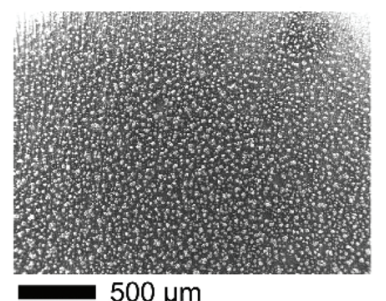

Fig. 7 Cycling performance of zinc electrodes and the morphologies of zinc deposits. (a-c) Galvanostatic voltage-time curves for a Zn/electrolyte/Zn symmetric cell with $0.4 \mathrm{M} \mathrm{Zn}(\mathrm{TfO})_{2} / \mathrm{IL}, 1.5 \mathrm{M} \mathrm{ZnO} / \mathrm{IL}$, and $\left(1.5 \mathrm{M} \mathrm{ZnO}+0.4 \mathrm{M} \mathrm{Zn}(\mathrm{TfO})_{2}\right) / / \mathrm{L}$, respectively, at a current density of $2 \mathrm{~mA} \mathrm{~cm}^{-2}$ and a capacity of $0.4 \mathrm{~mA} \mathrm{~h} \mathrm{~cm}{ }^{-2}$ for 170 cycles. (d-f) Optical photographs of $\mathrm{Zn}$ deposits after 170 cycles obtained from $\left.0.4 \mathrm{M} \mathrm{Zn(TfO}\right)_{2} / \mathrm{IL}, 1.5 \mathrm{M} \mathrm{ZnO/IL,}$ and (1.5 M ZnO + 0.4 M Zn(TfO) 2 )/IL, respectively. $(\mathrm{g}-\mathrm{i})$ The corresponding SEM images of the $\mathrm{Zn}$ deposits after 170 cycles.

deposition of very fine zinc structures as seen in Fig. 6e and $\mathrm{f}$. The sustainability of the innermost layer might also be a reason for not having dendritic growth as evidenced in Fig. $7 \mathrm{~g}$ after 170 cycles.

One concern towards practical application of the $\left(\mathrm{Zn}(\mathrm{TfO})_{2}\right.$ $+\mathrm{ZnO}) /[\mathrm{EIm}] \mathrm{TfO}$ electrolyte in dendrite-free zinc deposition is its high viscosity of $362 \mathrm{mPa} s$ at $25{ }^{\circ} \mathrm{C}$. However, it can be considerably reduced by adding water to the solution, and the solution still acts as an ionic liquid. ${ }^{42}$ Several investigations have revealed that upon addition of small amounts of water to ionic liquids, the zinc deposition was even facilitated and smooth zinc deposits were obtained as well as the cycling behavior was improved. ${ }^{57-59}$

\section{Conclusion}

In conclusion, we have demonstrated that the dendritic growth of zinc can be effectively suppressed in the $\left(\mathrm{Zn}(\mathrm{TfO})_{2}+\mathrm{ZnO}\right) /$ [EIm]TfO electrolyte. The Raman spectra show that cationic $\left[\mathrm{Zn}(\mathrm{EIm})_{2}\right]^{2+}$ complexes and anionic $\left[\mathrm{Zn}(\mathrm{TfO})_{4}\right]^{2-}$ complexes are present in the electrolyte. A synergetic effect of both cationic and anionic zinc complexes seems to prevent dendritic growth. The interfacial structure is significantly changed upon addition of $\mathrm{ZnO}$ and $\mathrm{Zn}(\mathrm{TfO})_{2}$ to [EIm]TfO which affects the nucleation and growth of zinc. Compact, homogeneous and dendrite-free zinc deposits are obtained in $\left(\mathrm{ZnO}+\mathrm{Zn}(\mathrm{TfO})_{2}\right) /$ [EIm]TfO. The cycling experiments show that the cells exhibit 
stable voltage during long-term cycling and dendrite-free zinc is observed at a current density of $2 \mathrm{~mA} \mathrm{~cm}^{-2}$ in $\left(\mathrm{Zn}(\mathrm{TfO})_{2}+\right.$ $\mathrm{ZnO}) /[\mathrm{EIm}] \mathrm{TfO}$.

\section{Experimental}

\section{Materials}

The ionic liquid, 1-ethylimidazolium trifluoromethylsulfonate, [EIm]TfO (99\%) and zinc trifluoromethylsulfonate, $\mathrm{Zn}(\mathrm{TfO})_{2}$ (99\%), in the highest quality, were purchased from IO-LI-TEC, Germany. Zinc oxide (99\%) was obtained from Sigma-Aldrich.

\section{Electrochemical measurements}

The cyclic voltammetry, chronoamperometry, chronopotentiometry, and galvanostatic charge-discharge test experiments were carried out in an argon-filled glove-box using a VersaStat III (Princeton Applied Research) potentiostat/galvanostat controlled by Power-CV and Power-Step software. The electrochemical cell made of polytetrafluoroethylene (Teflon) was clamped over a Teflon covered Viton O-ring. Prior to the experiments, the Teflon cell and the O-ring were cleaned in a mixture of 50:50 vol\% of concentrated $\mathrm{H}_{2} \mathrm{SO}_{4}$ and $\mathrm{H}_{2} \mathrm{O}_{2}$ followed by refluxing in distilled water. Gold substrates (gold on glass) from Arrandee Inc. were used as working electrodes. A platinum wire (Alfa, 99.99\%) was used as a counter electrode. Prior to each experiment, the Pt wire was cleaned with isopropanol in an ultrasonic bath for $15 \mathrm{~min}$ and annealed in a hydrogen flame to red glow in order to remove any possible contaminations. The reference electrode consists of a silver wire immersed in the employed IL containing $10 \mathrm{mM}$ silver trifluoromethylsulfonate (AgTfO), separated from the bulk solution by a glass frit (G4). Before using, a Nafion solution (LQ-1105 5\% by weight NAFION $®, 1100 \mathrm{EW}$ ) was filled in the glass frit and dried at $100{ }^{\circ} \mathrm{C}$ for $2 \mathrm{~h}$ to inhibit leakage. However, the potentials were referenced to the ferrocene/ferrocenium redox couple $\left(\mathrm{Fc} / \mathrm{Fc}^{+} 0.54 \mathrm{~V} v\right.$ s. $\left.\mathrm{Ag} / \mathrm{AgTfO}\right)$ in the experiments. A Zn/electrolyte/Zn symmetric cell was used for the cycling test. A zinc sheet was used as the working electrode and a zinc wire/sheet was used as the reference and counter electrodes, respectively.

\section{Characterization}

The deposits were characterized by scanning electron microscopy (Carl Zeiss DSM 982 Gemini). The X-ray diffraction patterns were recorded on a PANalytical Empyrean diffractometer. The Raman measurements were carried out with a Raman module FRA 106 (Nd:YAG laser, $1064 \mathrm{~nm}$ ) attached to a Bruker IFS 66v interferometer at room temperature. Atomic force microscopy (AFM) experiments were performed using a Molecular Imaging Pico Plus AFM in contact mode. A silicon SPM-sensor from Nano World was used for all experiments. The viscosity was measured on an AR1000/500 rheometer (TA Instrument, USA).

\section{Acknowledgements}

Financial support by the BMBF project LUZI (BMBF: 03SF0499A) is gratefully acknowledged.

\section{References}

1 P. Pei, K. Wang and Z. Ma, Appl. Energy, 2014, 128, 315324.

2 Y. Li and H. Dai, Chem. Soc. Rev., 2014, 43, 5257-5275.

3 H. Kim, G. Jeong, Y.-U. Kim, J.-H. Kim, C.-M. Park and H.-J. Sohn, Chem. Soc. Rev., 2013, 42, 9011-9034.

4 K. Bass, P. J. Mitchell, G. D. Wilcox and J. Smith, J. Power Sources, 1991, 35, 333-351.

5 C. W. Lee, K. Sathiyanarayanan, S. W. Eom and M. S. Yun, J. Power Sources, 2006, 160, 1436-1441.

6 Y.-D. Cho and G. T.-K. Fey, J. Power Sources, 2008, 184, 610616.

7 S.-M. Lee, Y.-J. Kim, S.-W. Eom, N.-S. Choi, K.-W. Kim and S.-B. Cho, J. Power Sources, 2013, 227, 177-184.

8 S. J. Banik and R. Akolkar, J. Electrochem. Soc., 2013, 160, D519-D523.

9 O. Aaboubi, J. Douglade, X. Abenaqui, R. Boumedmed and J. VonHoff, Electrochim. Acta, 2011, 56, 7885-7889.

10 M. Xu, D. G. Ivey, W. Qu and Z. Xie, J. Power Sources, 2015, 274, 1249-1253.

11 H. Li, C. Xu, C. Han, Y. Chen, C. Wei, B. Li and F. Kang, J. Electrochem. Soc., 2015, 162, A1439-A1444.

12 E. D. Woumfo and O. Vittori, J. Appl. Electrochem., 1991, 21, 77-83.

13 K. Leung, J. Phys. Chem. C, 2013, 117, 1539-1547.

14 F. Endres, O. Höfft, N. Borisenko, L. H. Gasparotto, A. Prowald, R. Al-Salman, T. Carstens, R. Atkin, A. Bund and S. Zein El Abedin, Phys. Chem. Chem. Phys., 2010, 12, 1724-1732.

15 T. L. Greaves and C. J. Drummond, Chem. Rev., 2008, 108, 206-237.

16 R. Hayes, G. G. Warr and R. Atkin, Chem. Rev., 2015, 115, 6357-6426.

17 A. P. Abbott, J. C. Barron, K. S. Ryder and D. Wilson, Chem. - Eur. J., 2007, 13, 6495-6501.

18 R. D. Rogers and K. R. Seddon, Science, 2003, 302, 792-793.

19 M. Armand, F. Endres, D. R. MacFarlane, H. Ohno and B. Scrosati, Nat. Mater., 2009, 8, 621-629.

20 T. Welton, Chem. Rev., 1999, 99, 2071-2084.

21 A. P. Abbott and K. J. McKenzie, Phys. Chem. Chem. Phys., 2006, 8, 4265-4279.

22 F. Endres, ChemPhysChem, 2002, 3, 144-154.

23 A. B. Pereiro, J. M. M. Araújo, F. S. Oliveira, J. M. S. S. Esperança, J. N. Canongia Lopes, I. M. Marrucho and L. P. N. Rebelo, J. Chem. Thermodyn., 2012, 55, 29-36.

24 Y.-F. Lin and I. W. Sun, Electrochim. Acta, 1999, 44, 27712777.

25 S. Tang, G. A. Baker and H. Zhao, Chem. Soc. Rev., 2012, 41, 4030-4066. 
26 F. Coleman, G. Srinivasan and M. Swadźba-Kwaśny, Angew. Chem., Int. Ed., 2013, 125, 12814-12818.

27 H. M. A. Abood, A. P. Abbott, A. D. Ballantyne and K. S. Ryder, Chem. Commun., 2011, 47, 3523-3525.

28 G. Pulletikurthi, B. Bödecker, A. Borodin, B. Weidenfeller and F. Endres, Prog. Nat. Sci., 2015, 25, 603-611.

29 Y. Fang, K. Yoshii, X. Jiang, X.-G. Sun, T. Tsuda, N. Mehio and S. Dai, Electrochim. Acta, 2015, 160, 82-88.

30 N. R. Brooks, S. Schaltin, K. Van Hecke, L. Van Meervelt, K. Binnemans and J. Fransaer, Chem. - Eur. J., 2011, 17, 5054-5059.

31 M. Steichen, N. R. Brooks, L. Van Meervelt, J. Fransaer and K. Binnemans, Dalton Trans., 2014, 43, 12329-12341.

32 J.-F. Huang, H. Luo and S. Dai, J. Electrochem. Soc., 2006, 153, J9-J13.

33 Z. Liu, S. Zein El Abedin and F. Endres, Electrochem. Commun., 2015, 58, 46-50.

34 N. Yaghini, J. Pitawala, A. Matic and A. Martinelli, J. Phys. Chem. B, 2015, 119, 1611-1622.

35 A. M. Moschovi, S. Ntais, V. Dracopoulos and V. Nikolakis, Vib. Spectrosc., 2012, 63, 350-359.

36 N. E. Heimer, R. E. Del Sesto, Z. Meng, J. S. Wilkes and W. R. Carper, J. Mol. Liq., 2006, 124, 84-95.

37 M. Majoube, M. Henry, L. Chinsky and P. Y. Turpin, Chem. Phys., 1993, 169, 231-241.

38 D. S. Caswell and T. G. Spiro, J. Am. Chem. Soc., 1986, 108, 6470-6477.

39 Y. Umebayashi, T. Fujimori, T. Sukizaki, M. Asada, K. Fujii, R. Kanzaki and S. Ishiguro, J. Phys. Chem. A, 2005, 109, 8976-8982.

40 J. X. Mao, A. S. Lee, J. R. Kitchin, H. B. Nulwala, D. R. Luebke and K. Damodaran, J. Mol. Struct., 2013, 1038, 12-18.

41 S. Cha, M. Ao, W. Sung, B. Moon, B. Ahlstrom, P. Johansson, Y. Ouchi and D. Kim, Phys. Chem. Chem. Phys., 2014, 16, 9591-9601.

42 Z. Liu, S. Zein El Abedin and F. Endres, ChemPhysChem, 2015, 16, 970-977.
43 C. M. Burba, N. M. Rocher and R. Frech, J. Phys. Chem. B, 2009, 113, 11453-11458.

44 R. Atkin, N. Borisenko, M. Drüschler, F. Endres, R. Hayes, B. Huber and B. Roling, J. Mol. Liq., 2014, 192, 44-54.

45 A. Lahiri, T. Carstens, R. Atkin, N. Borisenko and F. Endres, J. Phys. Chem. C, 2015, 119, 16734-16742.

46 R. Atkin and G. G. Warr, J. Phys. Chem. C, 2007, 111, 51625168.

47 T. Carstens, A. Ispas, N. Borisenko, R. Atkin, A. Bund and F. Endres, Electrochim. Acta, 2016, 197, 374-387.

48 H. Li, F. Endres and R. Atkin, Phys. Chem. Chem. Phys., 2013, 15, 14624-14633.

49 R. Hayes, D. Wakeham and R. Atkin, in Ionic Liquids Uncoiled, John Wiley \& Sons, Inc., 2012, pp. 51-85.

50 A. Elbourne, S. McDonald, K. Voïchovsky, F. Endres, G. G. Warr and R. Atkin, ACS Nano, 2015, 9, 7608-7620.

51 R. Atkin, S. Zein El Abedin, R. Hayes, L. H. S. Gasparotto, N. Borisenko and F. Endres, J. Phys. Chem. C, 2009, 113, 13266-13272.

52 S. Baldelli, Acc. Chem. Res., 2008, 41, 421-431.

53 J. Sniekers, N. R. Brooks, S. Schaltin, L. Van Meervelt, J. Fransaer and K. Binnemans, Dalton Trans., 2014, 43, 1589-1598.

54 L. N. Bengoa, S. Bruno, H. A. Lazzarino, P. R. Seré and W. A. Egli, J. Appl. Electrochem., 2014, 44, 1261-1269.

55 L. N. Bengoa, S. Bruno, H. A. Lazzarino, P. R. Seré and W. A. Egli, Procedia Mater. Sci., 2015, 8, 1174-1183.

56 S. Wellens, N. R. Brooks, B. Thijs, L. V. Meervelt and K. Binnemans, Dalton Trans., 2014, 43, 3443-3452.

57 Z. Liu, S. Zein El Abedin and F. Endres, Electrochim. Acta, 2013, 89, 635-643.

58 M. Kar, B. Winther-Jensen, M. Armand, T. J. Simons, O. Winther-Jensen, M. Forsyth and D. R. MacFarlane, Electrochim. Acta, 2016, 188, 461-471.

59 T. J. Simons, A. A. J. Torriero, P. C. Howlett, D. R. MacFarlane and M. Forsyth, Electrochem. Commun., 2012, 18, 119-122. 